\title{
The Physiology of \\ New York Boarding-Houses
}





\section{The Physiology of \\ New York Boarding-Houses}

Thomas Buther GunN

Edited and with an Introduction by David Faflik 
Library of Congress Cataloging-in-Publication Data

Gunn, Thomas Butler.

The physiology of New York boarding-houses / Thomas Butler Gunn ; edited and with an introduction by David Faflik.

p. $\mathrm{cm}$.

Originally published: New York : Mason Brothers, 1857.

Includes bibliographical references.

ISBN 978-0-8135-4439-7 (hardcover : alk. paper) — ISBN 978-0-8135-4440-3 (pbk. : alk. paper)

1. Lodging-houses-New York (State)—New York-19th century.

2. Boardinghouses—New York (State)—New York—19th century. 3. New York (N.Y.) Social life and customs - 19th century. I. Faflik, David, 1972- II. Title.

HD7288.U4G86 2009

647.9409747'109034-dc22

2008019780

A British Cataloging-in-Publication record for this book is available from the British Library.

The Physiology of New York Boarding-Houses was first published by Mason Brothers in 1857.

Introduction to this edition and scholarly apparatus copyright (c) 2009 by David Faflik

All rights reserved

No part of this book may be reproduced or utilized in any form or by any means, electronic or mechanical, or by any information storage and retrieval system, without written permission from the publisher. Please contact Rutgers University Press, 100 Joyce Kilmer Avenue, Piscataway, NJ 08854-8099. The only exception to this prohibition is "fair use" as defined by U.S. copyright law.

Visit our Web site: http://rutgerspress.rutgers.edu

Manufactured in the United States of America 
For the cities in our midst 
